\title{
Effects of Written Corrective Feedback on Explicit and Implicit Knowledge
}

\author{
Mitra Samiei \\ Tam Shu Sim
}

\begin{abstract}
This study is an examination of the effect of the different degrees of explicitness of written corrective feedback (WCF) on implicit and explicit knowledge of the target structure (past simple tense) in the short term and long term. There were four experimental groups including a control group, in this quasi-experimental study which received different degrees of explicit WCF. This study sought to investigate whether or not written corrective feedback could also be effective in targeting the problematic error category in the texts of FL writers. Past simple test was known as the problematic structure based on the result of the pre-test, though their level of proficiency was intermediate. It was found that both metalinguistic and direct WCF could affect the participants' explicit knowledge of the past simple tense in the short term and long term; the indirect WCF on the other hand, could only affect the explicit knowledge in the short term and the reformulation was the only kind of WCF that did not have any effect on the explicit knowledge of the past simple tense. Moreover, all the experimental groups' implicit knowledge improved in the short term; however, this improvement was sustained in the long term for the metalinguistic and indirect groups only.
\end{abstract}

Keywords: Written corrective feedback; explicitness of corrective feedback; explicit and implicit knowledge; experimental design; skill acquisition theory

\section{Introduction}

Giving feedback is one of the most appropriate pedagogical techniques used in foreign language and second language writing. The underlying assumption for giving corrective feedback is that it will help learners to notice their errors and, subsequently, produce the correct forms. Corrective feedback is also a pedagogical technique teachers use to draw attention to students' erroneous utterances, which may result in learners' modified output. To date, research on WCF has shown some interesting findings, but the contradiction of the results makes it clear that more research needs to be done. This study is an attempt to fill the gap in the literature on WCF and address the issues spelt out below.

Degree of explicitness of written corrective feedback

One of the aspects, which much debate has been centered on, is whether more or less explicit WCF is more beneficial in helping students improve their writing. It also led 
us to provide a continuum of different degree of explicitness of WCF that will be explained later in the discussion. Following Norris and Ortega (2000), Polio (2012) uses DeKeyser's (1995) definition of explicit and says that feedback is explicit if either a rule is given or if the learner has been directed to pay attention to a specific form. This is what Polio (2012) believed that all methods of WCF are considered explicit including reformulation because students, at least in experimental studies (e.g., Qi \& Lapkin, 2001; Sachs \& Polio, 2007) are told to look at the reformulations and note what has been changed.

Bitchener (2012) believed that intuitively one might expect metalinguistic information to be the most effective type of CF because, if it provides explicit rules, explanations, and examples, learners might be able to increase their understanding and process more deeply the knowledge they have been provided with. However, this may be dependent upon (1) the nature of the information provided, (2) the frequency with which they receive it, (3) the proficiency level of the learner, (4) the ability of the learner to relate it to other linguistic knowledge that s/ he may also be processing and consolidating, and (5) the complexity of the linguistic focus. Similarly, Ferris et al. (2013) assumed that more explicit WCF (with labels, codes, or other metalinguistic explanation) may be more valuable for some students than unlabeled CF. This finding may especially apply to L2 learners (e.g., those in EFL contexts) who have received a great deal of formal grammar instruction (that means grammatical rules are taught to them explicitly as a set of rules).They may benefit from WCF that includes specific terms or rule reminders, as the codes, corrections, or explanations may elicit their prior knowledge.

\section{Explicit and implicit knowledge}

Another aspect of WCF that is considered in writing research is whether WCF helps to improve the learners' implicit or explicit knowledge. Krashen (1982, 1985) distinguished between acquisition and learning while Ellis (2004) and others have distinguished between implicit unconscious procedural knowledge and explicit declarative knowledge.

Ellis (2004) added Implicit language knowledge refers to knowledge of a language that may be accessed instantaneously during spontaneous com-prehension or production. It differs from explicit language knowledge, which is knowl-edge about language and how the language can be used (Motoko, 2012). In general, disagreements concern the value of explicit and implicit knowledge in itself and the connection between explicit and implicit knowledge. This debate is important when exploring the effectiveness of error correction, because CF contestants (e.g. Krashen, 1982; Truscott, 1996) have stated that, if CF yields any L2 knowledge at all, this emerging knowledge could only be explicit in nature. However, Ferris (1999) believed that if the correction was clear and consistent, it would work for acquisition (implicit knowledge). Reviewing literature, Hyland and Hyland (2006) commented that "it is difficult to draw any clear conclusions and generalizations from the literature as a result of varied populations, treatments and research designs" (p. 84), implying that contextual factors influence the extent to which CF is effective.

Based on "Skill Acquisition Theory", Dekeyser (2001) asserts that explicit knowledge is needed for developing the implicit knowledge. He also claims that by deliberate and extensive practice the explicit knowledge can be changed to implicit knowledge. By practicing language 
production, L2 learners are able to consolidate and automatize their linguistic repertoire and $\mathrm{CF}$ is believed to further assist this process (R. Ellis, 2010).

So, following Skill Acquisition Theory, Ellis (2004) and other researchers have differentiated between explicit knowledge and implicit knowledge. However, it is not known which knowledge (explicit or implicit) learners draw upon while they are writing and whether WCF is stored as unconscious procedural knowledge or explicit declarative knowledge in the students' memory (Sheen 2007; Bitchener 2008). There has been only one study (Shintani \& Ellis, 2013) that has specifically addressed the effects of WCF on explicit and implicit knowledge. Therefore, this issue has yet to be investigated.

\section{Purpose of the study and research questions}

The purpose of this study was to investigate the effect of the different degrees of explicitness of WCF on explicit and implicit knowledge of the past simple tense in the short term and long term. The research questions are:

1) Is there any difference in the effect that different degrees of explicitness of feedback have on learners' explicit knowledge of past simple tense?

2) Is there any difference in the effect that different degrees of explicitness of feedback have on learners' implicit knowledge of past simple tense?

\section{Method}

\section{Participants}

The present study was conducted in the English language department of Payam-eNoor University in Ardabil (Iran). One hundred and five intermediate level learners (46 males, 59 female) participated in the study that ranged in age from 20 to 32 (average age: 23). Their first language was Azeri Turkish and second language was Persian, so the sample was hemoogeneous with regard to the language spoken. They were undergraduate students pursuing a bachelor's degree in translation studies. They were assigned to a writing proficiency test (PET), which proved that they were at intermediate level of writing. Then, students completed a background questionnaire, which revealed that all of them had received formal instruction in the English language for an average of seven years in high school and some of them had attended some English schools as well. Then, they were divided into five equal groups (20 in each experimental group and 25 in control group) randomly using numbers. There was a control group which did not receive any feedback and four experimental groups which received different degrees of explicit feedback on past simple tense which was problematic for them based on the pre-test. (It was believed that if teachers provide WCF on one or two targeted forms that were proved to be problematic for the learners, they could acquire a specific structure that they are ready to (Bitchener \& Knoch, 2009), because the acquisition of some forms has been proven to follow a natural order (Clahsen et al., 1983).

One of the experimental groups received metalinguistic feedback (it provides learners with some form of explicit comment about the nature of the errors they have made) which is considered the most explicit written corrective feedback. The second one received direct feedback which is less explicit than the metalinguistic explanation; they received the correct form of the error they had made under the erroneous structure. The third experimental group got the indirect feedback which is less explicit than the direct 
feedback, that is, it only specifies that in some way an error has been done by underlining the erroneous structure. The last group received the reformulation (which involves rewriting a learner's text, preserving all its ideas but removing their errors) of their writing which was handed to them in a separate paper.

\section{Materials}

Four instruments of data collection were used in this study: 1) Proficiency test: PET (it focused on the underlying knowledge of vocabulary and grammar. The exam included tasks such as completing gapped sentences, writing a short informal letter of $35-45$ words based on 3 given instructions, and producing a longer piece of writing either a long informal letter or a story of about 80-100 words) was administered and the result showed that there was no statistically significant difference among the groups ( $\mathrm{F}=.24, \mathrm{p}=.62), 2)$ Background questionnaire: a structured short questionnaire adapted from Liebman (1992) was distributed to the participants to check for learner homogeneity,3) Picture description test: picture composition tasks from Heaton (1975) were adapted to elicit stories from the students. Each picture sheet consisted of six pictures that described a short story. In accordance with N. Ellis' (2005) criteria, this test was designed to afford a potential measure of learners' implicit knowledge of the past simple tense, 4) Error correction test: this was adopted from the testing instrument used in Sheen (2007). It consisted of 16 items, each containing two related statements, one of which was underlined. The underlined sentence contained an error. The students were asked to write out the incorrect sentence correctly. The purpose of the test was to provide a measure of learners' explicit knowledge of the past simple tense.

\section{Procedures}

\section{Data collection procedure}

This study had a quasi-experimental design (a pre-test, immediate post-test, delayed post-test design). The design of the study was similar to Shintani and Ellis (2013)'s study that compared the influence of direct WCF and metalinguistic explanation on explicit and implicit knowledge of the learners. In Shintani and Ellis' study, they had three groups that participated in three sessions: in the first session they completed a background questionnaire, the error correction test (as pre-test) and the first writing task (picture description). In the second session the groups received their respective feedback and were asked to revise and then write the second writing task. At the third session, the groups in Shintani and Ellis's study completed their third writing task, after completing the exit questionnaire and then sat for the same error correction test as at the first session (also used as post-test).

This study, on the other hand, was designed to take 11 weeks (Table 1). In the first week, a background questionnaire and the first pre-test were administered to find out the problematic target structure. This was followed closely by the second pre-test (in the $2^{\text {nd }}$ week) that was an Error Correction Test and first writing assignment (Picture Description Test). Then, the teacher collected the learners' written stories and the researcher provided the considered feedback (metalinguistic, direct, indirect, and reformulation for the experimental groups). After that the teacher handed the comments back to the learners in the next session that is week 3 . Upon receiving the papers, the learners had time to examine the feedback and were asked to revise their writing. Then after a short break of 10 minutes in the same session, they were 
asked to write the next story. The story was different from the first task. Then, in weeks 4,5 , and 6 the same pattern was followed. One week later (week 7), immediate posttest (same pre-test) was given to find out the effects of the treatment in the short term. Finally, in order to report the possible effects of the treatment over time, a delayed post-test (same pre-test) was given in the $11^{\text {th }}$ week.

Table 1: Procedure of the study metalinguistic group outperformed the other groups.

this type of test (e.g., Ellis et al., 2008), the distractor items which were not to contain any errors were excluded from consideration in scoring the correction test (that means the test consisted of 16 items and 12 of the 16 items contained sentences with past simple tense errors. There were also four distractors, i.e. sentences containing other kinds of errors. These

\begin{tabular}{|c|c|c|c|c|c|c|}
\hline $\begin{array}{l}\text { Metalinguistic } \\
\text { Feedback }\end{array}$ & Week 1 & Week 2 & Weeks 3,4,5,6 & Week 7 & Week 8 & were not \\
\hline & \multirow{4}{*}{$\begin{array}{l}\text { First pre-test } \\
\text { (Picture- } \\
\text { description } \\
\text { test) and } \\
\text { background } \\
\text { questionnaire }\end{array}$} & \multirow{4}{*}{$\begin{array}{l}\text { Second pre-test } \\
\text { (Error- } \\
\text { correction) and } \\
\text { first writing } \\
\text { task (Picture } \\
\text { description) }\end{array}$} & \multirow{4}{*}{$\begin{array}{l}\text { Receiving the } \\
\text { respective feedback } \\
\text { and revising the } \\
\text { original writing } \\
\text { followed by new } \\
\text { piece of writing } \\
\text { (Picture description) } \\
* 5 \text { writing tasks } \\
\text { totally }\end{array}$} & \multirow{5}{*}{$\begin{array}{l}\text { Post-test (Error- } \\
\text { correction and } \\
\text { picture-description } \\
\text { test) }\end{array}$} & \multirow{4}{*}{$\begin{array}{l}\text { Delayed post-test } \\
\text { (Error-correction } \\
\text { and picture- } \\
\text { description test) }\end{array}$} & given a point \\
\hline Direct Feedback & & & & & & in the \\
\hline $\begin{array}{l}\text { Indirect } \\
\text { Feedback }\end{array}$ & & & & & & scoring. So \\
\hline Reformulation & & & & & & $\begin{array}{l}\mathrm{t} \quad \mathrm{h} \\
\mathrm{m} \text { a } x \text { i m u m } \\
\text { number was }\end{array}$ \\
\hline Control & & & No feedback & & & 16.) \\
\hline
\end{tabular}

\section{Data Analysis Procedure}

The scores of the Picture Description Test were calculated with regard to the percentages of forms correctly supplied in "obligatory occasions". Pica's (1994) "target-like use analysis" formula, i.e.

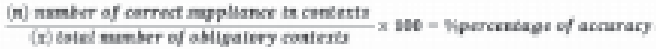

was used to derive the accuracy percentages for all the participating individuals in the current study (e.g., $\left.[5 / 10]{ }^{*} 100=50\right)$. In the error correction test, however, one point was awarded for successful correction of the target form in each sentence. In consistency with the literature available on significant difference between the groups in terms of the accuracy in using past simple tense in the pre-test and delayed posttest.Conversely, the groups' performance reached statistically significant difference in the immediate post-test. Table 3 below represents the descriptive statistics for the immediate post-test. It is revealed that the

\section{Results}

Effects on Explicit Knowledge

Arepeated-measures ANOVA was computed to show the difference across the three times (i.e. pre-test, immediate posttest, delayed post-test), the five groups (four experimental groups and a control group), and the interaction of time and group for the Error Correction Test. Table2 shows the results.

Table 2: Repeated-measure ANOVA result for error correction test

\begin{tabular}{|lrllll|}
\hline Effect & Value & F & \multicolumn{2}{c|}{ Error df } & Sig. \\
\hline Time & Wilks' Lambda 0.338 & 97.037 & 99.000 & $0.000^{*}$ \\
\hline $\begin{array}{l}\text { Time× } \\
\text { group }\end{array}$ & Wilks' Lambda 0.498 & 10.318 & 198.000 & $0.000^{*}$ \\
\hline
\end{tabular}

The results revealed that there was significance for both the time-effect $(F=$ 97.03, $p=.00(p<.05))$ and the time-group interaction effect $(F=10.31, p=.00(p<.05))$, 
but the effect of group was not significant. For a more in-depth analysis of the significance of time, the posthocpairwisebetween group comparisons using Bonferroni adjustment is reported and interpreted. The preliminary results disclosed that there was no statistically

Table 3: Descriptive statistics for the immediate post-test (error correction)

\begin{tabular}{|l|l|l|}
\hline Group & M & SD \\
\hline Metalinguistic & 9.55 & 1.43 \\
\hline Direct & 8.7 & 1.65 \\
\hline Indirect & 7.55 & 1.79 \\
\hline Reformulation & 7.1 & 1.8 \\
\hline Control & 6.4 & 1.97 \\
\hline
\end{tabular}

However, based on the results of the posthoc (Table 4), the metalinguisticgroup's mean score difference compared with the indirect, reformulation and control groups' scores was statistically significant. Moreover, the direct group had the second highest score in the immediate post-test and its difference with the reformulation and control group reached the significant level.

Table 4: The effect of time*group in immediate post-test (error correction)

\begin{tabular}{|lllll|}
\hline (I) group & (J) group & Mean Difference & Std. Error & Sig. \\
(I-J) & & & \\
Metalinguistic & Indirect & 2.000 & 0.555 & $0.005^{*}$ \\
Metalinguistic & Reformulation 2.450 & 0.555 & $0.000^{*}$ \\
Metalinguistic & Control & 3.150 & 0.526 & $0.000^{*}$ \\
Direct & Reformulation 1.600 & 0.555 & $0.048^{*}$ \\
Direct & Control & 2.300 & 0.526 & $0.000^{*}$ \\
\hline
\end{tabular}

\section{Effects on Implicit Knowledge}

As it was already declared, in order to test the learners' implicit knowledge of the past simple tense, the Picture Description Testwas given at three different times, as a pre-test, as immediate post-test and as delayed post-test.

Table 5: Repeated-measures ANOVA result for picture description test

\begin{tabular}{|lllcll|}
\hline Effect & & Value & F & Error df & Sig. \\
Time & Wilks' Lambda & 0.504 & 48.660 & 99.000 & $0.000 *$ \\
$\begin{array}{l}\text { Timex } \\
\text { group }\end{array}$ & Wilks' Lambda & 0.752 & 3.797 & 198.000 & $0.000 *$ \\
\hline
\end{tabular}

The scores obtained for the repeatedmeasures ANOVA clarified that there was significant effect for time $(F=48.66, p=.00)$ and also a significant time-group effect $(F$ $=3.79, p=.00$ ) but the group effect did not reach a significant difference $(p<.05)$ (Table 5). Therefore, the post hoc pair-wise between group comparisons using Bonferroni adjustment were administeredagain similar to the Error Correction Test. The result is reported in Table 6 and 8.

Table 6: The effect of time* group in immediate post-test (picture description test)

\begin{tabular}{|llrll|}
\hline (I) group & (J) group & $\begin{array}{c}\text { Mean } \\
\text { Difference (I-J) }\end{array}$ & Std. Error & Sig. \\
\hline Control & Metalinguistic & -20.109 & 3.823 & $0.000^{*}$ \\
Control & Direct & -20.588 & 3.823 & $0.000^{*}$ \\
Control & Indirect & -22.997 & 3.823 & $0.000^{*}$ \\
Control & Reformulation & -16.297 & 3.823 & $0.000^{*}$ \\
\hline
\end{tabular}

Post hoc pair-wise between group comparisons using Bonferroni adjustment revealed that there was no significant difference between the groups in the pre-test in terms of the accuracy in past simple tense. However, Table5 revealsthat in the immediate post-test there was statistically significant difference between the control group and all the experimental groups $(p=$ $.00)$. 
Table 7: Descriptive statistics for immediate post-test (picture description test)

\begin{tabular}{|l|l|l|}
\hline Group & M & SD \\
\hline Metalinguistic & 79.57 & 14.17 \\
\hline Direct & 80.05 & 11.49 \\
\hline Indirect & 82.46 & 9.97 \\
\hline Reformulation & 66.27 & 14.16 \\
\hline Control & 59.46 & 9.45 \\
\hline
\end{tabular}

As Table7 illustrates, the descriptive statistics for the immediate post-test shows that all the experimental groups (metalinguistic, direct, indirect, and reformulation) outperformed the control group in terms of the accurate use of past simple tense. There was also a statistically significant difference between the control group and the metalinguistic group in the delayed post-test (Table 8).

Table 8: The effect of time*group in delayed post-test (picture description)

\begin{tabular}{|lllll|}
\hline (I) group & (J) group & $\begin{array}{c}\text { Mean } \\
\text { Difference (I-J) }\end{array}$ & Std. Error & Sig. \\
\hline Control & Metalinguistic & -15.994 & 3.788 & $0.001^{*}$ \\
\hline
\end{tabular}

Table 9: Descriptive statistics for delayed post-test (picture description test)

\begin{tabular}{|l|l|l|}
\hline Group & M & SD \\
\hline Metalinguistic & 73.94 & 13.90 \\
Direct & 65.83 & 12.10 \\
Indirect & 65.94 & 11.58 \\
Reformulation & 75.76 & 17.58 \\
Control & 57.94 & 11.40 \\
\hline
\end{tabular}

According to the Table 8, the descriptive statistics for the delayed post-test reveals that similar to the immediate post-test, the control group had the lowest score compared to the experimental groups, though its difference only with the metalinguistic group was statistically significant (Table 8). To answer the research questions, the results suggest that there was a difference in the effect that different degrees of explicit WCF had on the development of the learners' explicit and implicit knowledge of the past simple tense. In the first place, both metalinguistic and direct WCF could affect the participants' explicit knowledge of the past simple tense in the short term effect and long term effect; the indirect WCF on the other hand, could only affect it in the short term and the reformulation was the only kind of WCF that did not have any effect on the explicit knowledge of the past simple tense (Table $10)$.

Table 10: Summary of the results and answers to the research questions

\begin{tabular}{|l|l|l|l|}
\hline & $\begin{array}{c}\text { Feedback } \\
\text { Types }\end{array}$ & $\begin{array}{c}\text { Explicit } \\
\text { Knowledge }\end{array}$ & \multicolumn{1}{|c|}{$\begin{array}{c}\text { Implicit } \\
\text { Knowledge }\end{array}$} \\
\hline $\begin{array}{l}\text { More } \\
\text { explicit }\end{array}$ & $\begin{array}{l}\text { Metalinguistic } \\
\text { WCF }\end{array}$ & $\begin{array}{l}\text { yes (short \& } \\
\text { long term) }\end{array}$ & $\begin{array}{l}\text { yes (short \& } \\
\text { long term) }\end{array}$ \\
\hline & Direct WCF & $\begin{array}{l}\text { yes (short \& } \\
\text { long term) }\end{array}$ & $\begin{array}{l}\text { no (short \& } \\
\text { long term) }\end{array}$ \\
\hline $\begin{array}{l}\text { Less } \\
\text { explicit }\end{array}$ & $\begin{array}{l}\text { Indirect } \\
\text { WCformulation }\end{array}$ & $\begin{array}{l}\text { yes (short } \\
\text { term) }\end{array}$ & $\begin{array}{l}\text { yes (short \& } \\
\text { long term) }\end{array}$ \\
\hline
\end{tabular}

In the second place, all the experimental groups' implicit knowledge improved in the short term, but this improvement was sustained in the long term for the metalinguistic and indirect group. So, it suggests that the metalinguistic and indirect WCF could be affective in improving the implicit knowledge of the past simple tense. The findings of the study propose, then, that if the goal of written error feedback is to develop learners' explicit knowledge, the metalinguistic and direct WCF may be a more effective means of achieving this than the indirect and reformulation WCF. Furthermore, if it aims to improve the 
implicit knowledge, the metalinguistic and indirect WCF might be more effectual.

\section{Discussion}

Degree of Explicitness of WCF

In this study, based on the information provided by the teacher about the error, each type of WCF is placed in a continuum ranging from more explicit to less explicit: 1 ) metalinguistic 2) direct 3) indirect 4) reformulation as the figure (1) below shows:

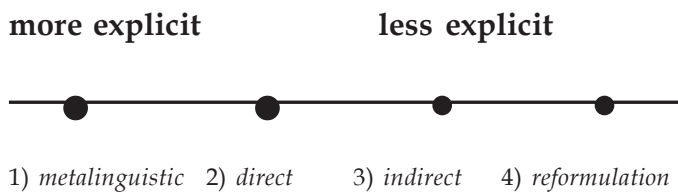

Figure 1: Continuum for the degree of explicitness of WCF

Although, there are studies that found no difference between the different types of WCF (e.g. Lalande, 1982; Semke, 1984; Robb et al., 1986), different research findings in the literature suggest various implications on the superiority of WCF techniques (e.g. Bitcheher et al., 2005; Chandler, 2003; R. Ellis, 2008). As far as can be determined, there is no single study which investigated the continuum of written corrective feedback from the perspective of the degree of explicitness specifically, although the degree of explicitness of oral corrective feedback has already been investigated in the literature (for example: Carroll and Swain, 1993). Their finding was different from the findings of this study. In this study, all the experimental groups performed better than the control group in the short term. The metalinguistic and indirect WCF did not lose their effect in the long term. The findings from the delayed post-test confirmed the superiority of the metalinguistic and indirect WCF over reformulation and direct WCF in the long term. Metalinguistic and indirect WCF had durable positive effects on subject's performance in both of the tests.

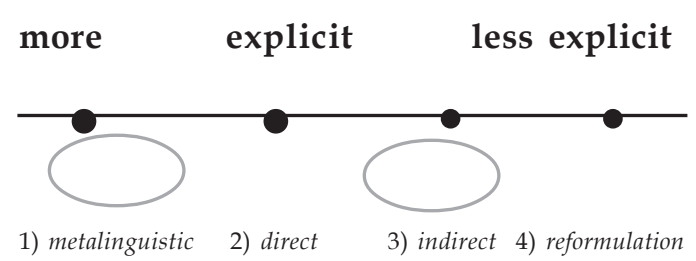

Figure 2: Superiority of the metalinguistic and indirect WCF

As the figure (2) above shows, there was not a linear pattern in the efficacy of the different degrees of the explicitness of WCF. While the most explicit kind of WCF(metalinguistic) was effective in improving the target structure (past simple tense), the less explicit kind of WCF (indirect) has the same effect as well. Although Sheen's (2010) postulation that the degree of explicitness plays a pivotal role in making feedback beneficial for the learners is seconded here; other reasons and factors for the different efficacy of each feedback type are possible and are explained below.

In this EFL study, one of the potential reasons for the efficacy of metalinguistic WCF over the other types of WCF could be due to familiarity. Most of the schools in Iran practice metalinguistic WCF. Another possible aspect is the selection of target form to be corrected. Further, Schmidt $(1995,2001)$ distinguished awareness at the level of noticing and at the level of understanding, which is a higher level of awareness. Noticing involves simply attending to exemplars of specific forms in the input, understanding entails knowing a rule or principle that governs that aspect of language. Thus, it can be argued that whereas both metalinguistic and direct WCF 
are likely to promote awareness as noticing, only metalinguistic comments promote awareness with understanding. An important aspect of the metalinguistic feedback is that students examine and understand the rules governing the linguistic structures they used so that they can employ the correct forms in the future. Based on the results of the study it is apparent that direct feedback only is not enough for students to improve their writing skills because they do not have to reflect on the corrected mistakes. They simply copy the corrected speech into the new draft. Direct WCF is not as effective in helping students avoid errors because it only draws their attention to an error in grammatical category, but not to a rule. Besides the metalinguistic type of WCF, indirect WCF, which assigned the responsibility for correction to learners themselves was also effective in the long term. In this respect, the findings of this study seemed slightly different from the literature. Rare studies on comparing the durable effects of different types of WCF revealed the superiority of indirect corrective feedback over time (for example Ferris et al., 2000 and Chandler, 2003).

As mentioned earlier, in general, the reformulation and direct groups' performance was improved just in the short term. The possible explanation for the inefficacy of reformulation in the long term might relate to the very nature of the reformulation process which usually entails that students may not have noticed the correction of their errors. In addition, as noted by Sachs and Polio (2007) in relation to their own data, the greater visual saliency which characterizes error corrections may facilitate uptake. Along the same lines, Sheen (2010) goes as far as suggesting that more explicit CF types "enable learners to notice the gap between their non-target output and the correct form; this, in turn, facilitates interlanguage development" (p. 226).
Furthermore, a caveat suggested in research is that some types of feedback are more useful in treating some types of error than others, though there is no definite answer to it. In line with the Bitchener et al. s' (2005) findings, this study suggested that treatable errors such as verb tense should be treated with metalinguistic or indirect WCF for improving learners' performance in the long term.

Last but not the least, the degree of explicitness required may hinge upon other factors such as learners' levels of proficiency (e.g., Philp, 2003; VanPatten, 1990), readiness for certain linguistic features (e.g., Han, 2002, Mackey \& Philp, 1998; Philp, 2003), the linguistic features targeted (e.g., Doughty \& Williams, 1998; Gass et al., 2003; Schmidt, 1995; VanPatten, 1994), and the contexts where feedback is provided (e.g., Ellis et al., 2001; Nicholas et al., 2001; Oliver \& Mackey, 2003). Such factors merit careful examination to isolate optimal ways to promote learners' noticing of the gap. Such explorations would form the basis for the future studies in WCF.

\section{Conclusion}

The purpose of this study was to investigate the effect of the different degrees of explicitness of WCF on explicit and implicit knowledge of the past simple tense in the short term and long term. The results confirmed the superiority of the metalinguistic and indirect WCF over reformulation and direct WCF in long term. Metalinguistic and indirect WCF had durable positive effects on subjects' performance in both of the tests. Moreover, the result of the Picture Description Test as a measure of implicit knowledge revealed that the metalinguistic and indirect WCF were the most effective WCF types in developing the implicit knowledge of the learners. Measuring the explicit knowledge by the Error Correction Test, it was found that the 
provision of more explicit WCF (metalinguistic and direct) resulted in significantly greater accuracy when the past simple tense was tested in the short term and long term, So, the more explicit types of WCF (metalinguistic and direct) could affect the explicit knowledge of the past simple tense positively. It is worthwhile to mention that the indirect WCF (less explicit than the metalinguistic and direct WCF) just has a short term effect on improving the explicit knowledge and the least explicit kind of the WCF, that is, reformulation had no effect on the explicit knowledge of the past simple tense.

Overall, the study favored written corrective feedback in general and metalinguistic and indirect WCF more specifically for the Iranian EFL context. The findings of this study not only indicate the immediate effect of written corrective feedback on writing but also the extent to which the level of accuracy was retained over a month period without additional corrective feedback and classroom instruction. Metalinguistic and indirect WCF could lead to the improvement of the implicit knowledge of the past simple tense. It can be claimed that this long term effectmeans that the learners have acquired the target structure. Nevertheless, the findings of this study proposes that if the goal of WCF is to develop learners' explicit knowledge of the past simple tense, the metalinguistic and direct WCF may be a more effective means of achieving this than the indirect and reformulation WCF. Furthermore, if it aims to improve the implicit knowledge of the past simple tense, the metalinguistic and indirect WCF might be more effectual.

\section{References}

Bitchener, J. (2008). Evidence in support of written corrective feedback. Journal of Second Language Writing, 17(2), 102118.
Bitchener, J. (2012). A reflection on 'the language learning potential' of written CF. Journal of Second Language Writing, 21(4), 348-363.

Bitchener, J., \& Knoch, U. (2008). The value of written corrective feedback for migrant and international students. Language Teaching Research, 12, 409_ 431.

Bitchener, J., \& Knoch, U. (2009). The value of a focused approach to written corrective feedback. ELT Journal, 63(3), 204-211.

Bitchener, J., Young, S., \& Cameron, D. (2005). The effect of different types of corrective feedback on ESL student writing. Journal of Second Language Writing, 14, 191-205.

Carroll, S., \& Swain, M. (1993). Explicit and implicit negative feedback: An empirical study of the learning of linguistic generalization. Studies in Second Language Acquisition, 15, 357386.

Chandler, J. (2003). The efficacy of various kinds of error feedback for improvement in the accuracy and fluency of L2 student writing. Journal of Second Language Writing, 12, 267296.

Clahsen, H., Meisel, J. M., \& Pienemann, M. (1983), Deutsch als Zweitsprache: Der Spracherwerb ausländischer Arbeiter. Tübingen: Gunter Narr Verlag.

DeKeyser, R. (1995). Learning second language grammar rules: An experiment with a miniature linguistic system. Studies in Second Language Acquisition, 17, 379-410.

DeKeyser, R. (2001). Automaticity and automatization. In P. Robinson (Ed.), Cognition and second language instruction (pp. 125-151). Cambridge, England: Cambridge University Press. 
Doughty, C., \& Williams, J. (1998). Focus on form in classroom second language acquisition. Cambridge: Cambridge University Press.

Ellis, N. (2005). At the interface: Dynamic interactions of explicit and implicit language knowledge. Studies in Second Language Acquisition, 27(2),305-352.

Ellis, R. (2004). The definition and measurement of L2 explicit knowledge. Language Learning,52(2), 227-75.

Ellis, R. (2008). A typology of written corrective feedback types. ELT Journal, 63(2), 97-107.

Ellis, R. (2010). A framework for investigating oral and written corrective feedback. Studies in Second Language Acquisition, 32(2), 335-349.

Ellis, R., Basturkmen, H., \& Loewen, S. (2001). Leaner uptake in communicative ESL lessons. Language Learning, 51, 281-318.

Ellis, R., Sheen, Y., Murakami, M., \& Takashima, H. (2008). The effects of focused and unfocused written corrective feedback in an English as a foreign language context. System, 36, 353-371.

Ferris, D. R. (1999). The case for grammar correction in L2 writing classes: A response to Truscott (1996). Journal of Second Language Writing, 8(1), 1-11.

Ferris, D. R., Liu, H., Sinha, A., \& Senna, M. (2013). Written corrective feedback for individual L2 writers. Journal of Second Language Writing, 22, 307-329.

Gass, S., Svetics, I., \& Lemelin, S. (2003). Differential effects of attention. Language Learning, 53, 497-545.

Han, Z. H. (2002). A study of the impact of recasts on tense consistency in L2 output. TESOL Quarterly, 36, 543-572.
Heaton, J. (1975). Beginning composition through pictures. London: Longman.

Hyland, F., \& Hyland, K. (2006). Feedback in second language writing: Contexts and issues. Cambridge: Cambridge University Press.

Krashen, S. (1982). Principles and practice in second language acquisition. Oxford: Pergamon.

Krashen, S. (1985). The input hypothesis. Torrance, CA: Laredo Publishing Company.

Lalande, J. F. (1982). Reducing composition errors: An experiment. Modern Language Journal, 66, 140-149.

Liebman, J. D., (1992). Toward a new contrastive rhetoric: differences between Arabic and Japanese rhetorical instruction. Journal of Second Language Writing, 1(2), 141-165.

Mackey, A. \& Philp, J (1998). Conversational interaction and second language development: Recasts, responses, and red herrings? The Modern Language Journal, 82, 338-356.

Motoko, A. (2012). Evaluating the effectiveness of explicit instruction on implicit and explicit L2 knowledge. Language Teaching Research, 16 (1), 937.

Nicholas, H., Lightbown, P. M., \& Spada, N. (2001). Recasts as feedback to language learners. Language Learning, 51, 719758.

Norris, J. M., \& Ortega, L. (2000). Effectiveness of L2 instruction: A research synthesis and quantitative meta-analysis. Language Learning, 50, 417-527.

Oliver, R., \& Mackey, A. (2003). Interactional context and feedback in child ESL classrooms. Modern Language Journal, 87, 519-533. 
Philp, J. (2003). Constraints on "noticing the gap". Studies in Second Language Acquisition, 25(01), 99-126.

Pica, T. (1994). Research on negotiation: What does it reveal about secondlanguage learning condition, processes, and outcomes? Language Learning, 44, 493-527.

Polio, C. (2012). The relevance of second language acquisition theory to the written error correction debate. Journal of Second Language Writing, 21(4), 375389.

Qi, D. S., \& Lapkin, S. (2001). Exploring the role of noticing in a three-stage second language writing task. Journal of Second Language Writing, 10, 277-303.

Robb, T., Ross, S., \& Shortreed, I. (1986). Salience of feedback on error and its effect on EFL writing quality. Tesol Quarterly, 20(1), 83-96.

Sachs, R., \& Polio, C. (2007). Learners' uses of two types of written feedback on an L2 writing revision task. Studies in Second Language Acquisition, 29, 67-100.

Schmidt, R. (1995). Attention \& awareness in foreign language learning. Hawaii: University of Hawaii Press.

Schmidt, R. (2001). Attention. In P. Robinson (Ed.), Cognition and Second Language Instruction (pp. 3-32). Cambridge: Cambridge University.

Semke, H. (1984). The effects of the red pen. Foreign Language Annals, 17, 195-202.

Sheen, Y. (2007). The effect of focused written corrective feedback and language aptitude on ESL learners' acquisition of articles. TESOL Quarterly, 41, 255-283.

Sheen, Y. (2010). Differential effects of oral and written corrective feedback in the ESL classroom. Studies in Second Language Acquisition, 32, 201-234.
Shintani, N., \& Ellis, R. (2013). The comparative effect of direct written corrective feedback and metalinguistic explanation on learners' explicit and implicit knowledge of the English indefinite article. Journal of Second Language Writing, 22, 286-306.

Truscott, J. (1996). The case against grammar correction in L2 writing classes. Language Learning, 46, 269-327.

VanPatten, B. (1990). Attending to form and content in the input: An experiment in consciousness. Studies in Second Language Acquisition, 12, 287-301.

VanPatten, B. (1994). Evaluating the role of consciousness in second language acquisition: Terms, linguistic features and research methodology. AILA Review, 11, 27-36.

The authors: Mitra Samiei is a PhD candidate in Language Learning and Assessment at the University of Malaya in Malaysia. She has been supervised by Dr. Tam Shu Sim during her PhD journey. She has done her Masters in English Language Education and Bachelors in English Language and Literature at Azad University in Iran. Her area of interest is Written Corrective Feedback.

Tam Shu Sim is a senior lecturer at the Faculty of Languages and Linguistics, University of Malaya. The faculty is currently ranked top 100 in the QS ranking for the subject, English language. She publishes in the field of Applied Linguistics specifically, English as a second language and she supervises both MA and PhD students. 